\title{
Efficiency of Brick Dust and Powdered Ceramsite in the Phosphorus Removal from Wastewater
}

\author{
Adam Masłoń ${ }^{*}$, Joanna Czarnota ${ }^{1}$ \\ 1 Department of Environmental Engineering and Chemistry, Rzeszow University of Technology, \\ Powstańców Warszawy 6, 35-959 Rzeszów, Poland \\ * Corresponding author's e-mail: amaslon@prz.edu.pl
}

\begin{abstract}
The biological methods of removing the phosphorus compounds from wastewater as applied currently at treatment plants may no longer be regarded as sufficient. They can therefore be augmented with physicochemical methods, raising the efficiency of the wastewater treatment system. Indeed, almost all large urban wastewater treatment plants practice precipitation of phosphorus using salts of iron and aluminum in the form of chemical coagulants. Nevertheless, the search for new ways of assisting with the removal of the biogenic element from wastewater, e.g. by dosing bentonites, fly ash and post-technological sludge from water treatment stations, or even unconventional organic sorbents such as rice husks, is ongoing. A further unconventional material in the P-removal from wastewater may take the form of powdered mineral materials. The work presented here shows the results of laboratoryscale trials on the P-removal using brick dust and powdered ceramsite (expanded clay).
\end{abstract}

Keywords: phosphorus, wastewater, P-removal, powdered materials, ceramsite, brick dust

\section{INTRODUCTION}

Excessive concentrations of the compounds of phosphorus degrade the aquatic ecosystems, even to the extent that the affected waters may have to be excluded from the economic, recreational or natural use [Bowes et al., 2015; Bunce et al., 2018]. One of the sources of the element flowing into aquatic ecosystems, primarily surface waters, is the municipal wastewater, in which the concentration and form of $\mathrm{P}$ occurrence depends on the applied methods and efficiencies of wastewater treatment. The P-removal in conventional biological wastewater treatment systems relies upon assimilation, as a direct reflection of the demand for the nutrient exerted by the synthesis of new biomass. The biological removal can also be intensified by exploiting the capacity of the heterotrophic bacteria dubbed PhosphateAccumulating Organisms (PAOs) to accumulate the excess cellular phosphate in the form of polyphosphate grains [Lanham et al., 2013].
The methods of biological dephosphatation employed at wastewater treatment plants are no longer regarded as sufficient [Trikoilidou et al., 2016], so it is typical for auxiliary support to be offered by means of the physicochemical methods increasing the efficiency in the wastewater treatment system [Cieślik and Konieczka, 2017]. Almost all large municipal wastewater treatment plants engage in the precipitation of phosphorus using the compounds of iron and aluminum, i.e. coagulants of the PIX and PAX type [Caravelli et al., 2010]. One way to remove the phosphorus compounds from wastewater is to use the reactive materials, i.e. those capable of the selective removal of specific substances by sorption or precipitation [Cucarella and Renman, 2009]. Recently, new methods to assist with the P-removal have entailed bentonites [Yan et al., 2010], La(III)-modified bentonite [Kuroki et al., 2014; Kasprzyk and Gajewska, 2017], silica filter [Kim et al., 2012], steel slag [Li et al., 2018], shale ash [Kõiv et al., 2010], calcite [Liu et al., 2012], Light 
Expanded Clay Aggregates [Kaczmarczyk et al., 2017], the carbonate-siliceous rock called opoka [Cucarella et al., 2009; Kasprzyk \& Gajewska, 2019], zeolited fly ash [Wu et al., 2006], Polly$\operatorname{tag}{ }^{\circledR}$ lightweight aggregate [Bus et al., 2014], water processing sludge [Totczyk et al., 2015], and sun coral powder [Vianna et al., 2016]. Unconventional materials have also been employed for this purpose, including rice husks [Yadav et al., 2015], Portland Cement [Masłon, 2016] or dolomite-modified biochar [Li et al., 2019].

Further unconventional materials capable of being applied in the P-removal from wastewater comprise powdered ceramsite or brick dust.

\section{METHODS AND MATERIALS}

\section{Brick dust and powdered ceramsite}

The study materials were the powdered fraction of lightweight expanded clay called "ceramsite" (PK) - which is generated in the course of the sorting process relating to the coarse aggregate of Leca ${ }^{\circledR}$ KERAMZYT, from the Weber Production Plant in Gniew (Saint-Gobain Construction Products Poland); as well as brick dust (BD) from the brickyard in Radoszyce (CERADBUD Ltd Poland) (Figure 1).

Leca ${ }^{\circledR}$ KERAMZYT is a porous material formed from a geochemically-specific clay fired at high temperatures in a rotary kiln. Such a process ensures that expanded clay is a mineral material, with total sterilisation reflecting the treatment at temperatures above $1100^{\circ} \mathrm{C}$.

Brick dust is a commercial product in which ground waste brick aggregate is mixed with red ground clay in a 10:1 ratio, gaining subsequent use in the construction of surfaces at sports facilities (on tennis courts, playgrounds, treadmills, etc.). Brick dust resembles the above-mentioned ceramsite in being a mineral material.

The two materials deployed in the experiments to be detailed here different markedly with respect to their contents of silica, aluminium, calcium and iron. Specifically, the chemical compositions of these powdered materials are as detailed in Table 1. However, PK and BD are both alkaline, with the $\mathrm{pH}$ values of tested samples being 10.1 and 9.9 , respectively.

The granulometric analysis conducted using a laser diffraction technique on a Mastersizer 2000 (from Malvern Instruments Ltd.) revealed different particle-size distributions (PSDs) (Figure 2). The parameters identifying particle fineness and uniformity are as supplied in Table 2. Equally, the values for specific surface area of PK and BD samples were found to be at a similar level, amounting to 5.183 and $4.861 \mathrm{~m}^{2} / \mathrm{g}$, respectively. The sample particle densities were of $2.68 \mathrm{~g} / \mathrm{mL}$ in both cases.

Table 1. Chemical characteristics of the powdered materials used

\begin{tabular}{|c|c|c|}
\hline Component [\%] & $\mathrm{PK}$ & $\mathrm{BD}$ \\
\hline $\mathrm{SiO}_{2}$ & 46.28 & 62.33 \\
\hline $\mathrm{Al}_{2} \mathrm{O}_{3}$ & 17.56 & 18.83 \\
\hline $\mathrm{Fe}_{2} \mathrm{O}_{3}$ & 12.91 & 7.29 \\
\hline $\mathrm{CaO}$ & 10.62 & 2.14 \\
\hline $\mathrm{MgO}$ & 3.58 & 2.24 \\
\hline $\mathrm{Na}_{2} \mathrm{O}$ & 0.55 & 1.20 \\
\hline $\mathrm{K}_{2} \mathrm{O}$ & 4.81 & 3.94 \\
\hline $\mathrm{eqNa}_{2} \mathrm{O}$ & 3.72 & 3.80 \\
\hline $\mathrm{SO}_{3}$ & 0.86 & 0.12 \\
\hline $\mathrm{Cl}^{-}$ & 0.03 & 0.01 \\
\hline
\end{tabular}

eqNa $2 \mathrm{O}$ - calculated as $\mathrm{Na}_{2} \mathrm{O}+0.66 \mathrm{~K}_{2} \mathrm{O}$
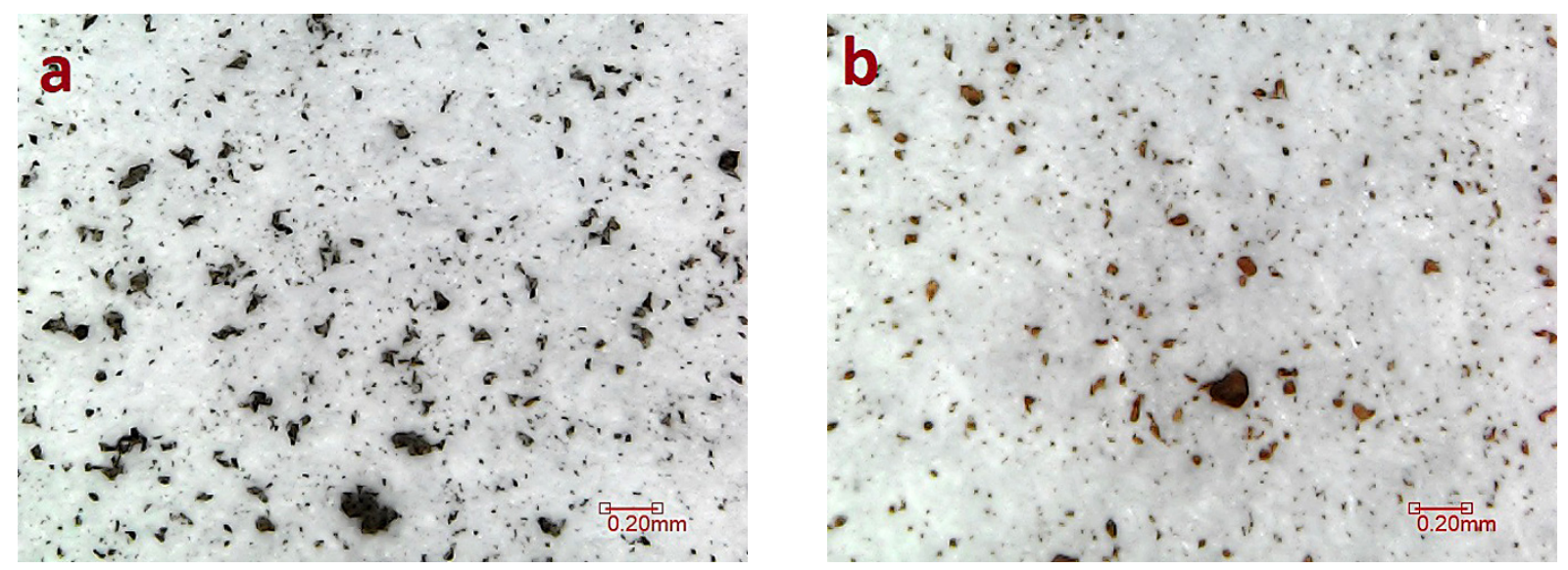

Figure 1. Images of powdered materials used in the study ( $\mathrm{a}$ - powdered ceramsite, $\mathrm{b}$ - brick dust) 


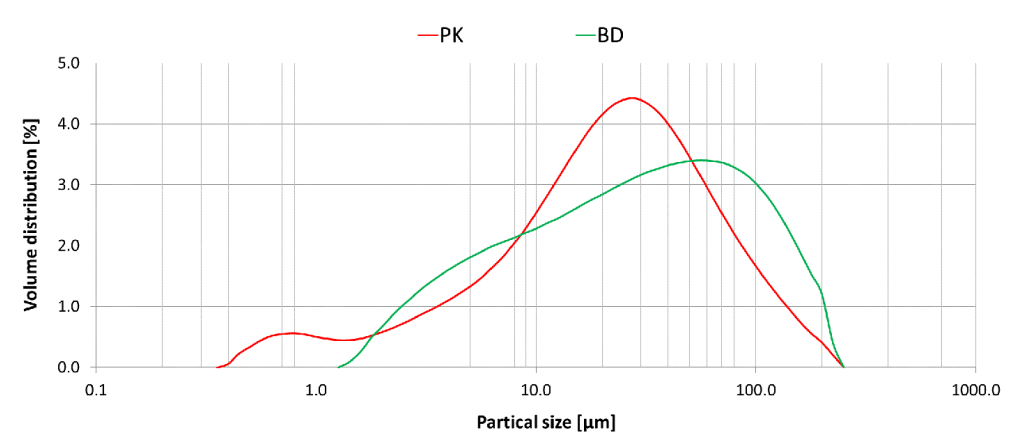

Figure 2. Particle-size distributions characterising the powdered materials

\section{Phosphorus adsorption experiments}

The static non-flow conditions were used to study the capacity for the phosphorus sorption manifested by the tested materials. To this end, a model solution of phosphorus concentration equal to $1.0 \mathrm{~g} \mathrm{P} / \mathrm{dm}^{3}$ was prepared using deionised water and $\mathrm{KH}_{2} \mathrm{PO}_{4} .12$ conical flasks were dosed with $1 \mathrm{~g}$ of $\mathrm{PK}$ or $\mathrm{BD}$ and $50 \mathrm{~cm}^{3}$ of the model solution at $\mathrm{mg} \mathrm{P} / \mathrm{dm}^{3}$ concentrations of 2 , $5,10,20,40,60,80,100,125,150,175$ and 200. The samples were then shaken mechanically for $24 \mathrm{~h}$ at $20^{\circ} \mathrm{C}$, prior to determinations for total $\mathrm{P}$ being carried out on filtered solution, in accordance with PN-EN 1189: 2000. The data obtained gained description using the Langmuir isotherm equation 1

$$
\frac{\mathrm{C}_{\mathrm{e}}}{\mathrm{q}_{\mathrm{e}}}=\frac{1}{\mathrm{q}_{\mathrm{m}}} \cdot \mathrm{C}_{\mathrm{e}}+\frac{1}{\mathrm{~K}_{\mathrm{L}} \cdot \mathrm{q}_{\mathrm{m}}}
$$

where $C_{e}$ is the equilibrium concentration of phosphorus in the liquid phase $\left[\mathrm{mg} \mathrm{P} / \mathrm{dm}^{3}\right]$ $q_{m}$ is the maximum sorption capacity according to the Langmuir model $[\mathrm{mg} \mathrm{P} / \mathrm{g}$ ] $q_{\mathrm{e}}$ is the amount of phosphorus adsorbed by the powdered material, i.e. PK or BD [mg P/g] $K_{L}$ is the Langmuir constant

\section{Batch experiments}

The trials relating to the P-removal were carried out using a batch test conducted as follows: 5 beakers of 1-litre capacity were filled with municipal wastewater, prior to the addition of one or other of the powdered materials (powdered ceramsite or brick dust), in amounts equal

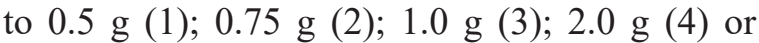
$5.0 \mathrm{~g} \mathrm{(5)}$. The beakers were placed in a mechanical stirrer, and slow mixing was engaged in. The values for $\mathrm{pH}$ and electrolytic conductivity were measured following the stirring, before the solutions were filtered in advance of the phosphate determinations (in accordance with PN-EN ISO 6878). The $\mathrm{pH}$ was determined using a Hach Lange HQ40d Multi meter. Each measurement series was run in triplicate, and tests were carried out on wastewater at a temperature of ca. $20^{\circ} \mathrm{C}$. The municipal wastewater used in the studies was derived from the Rzeszów Wastewater Treatment Plant (WWTP), and was actually characterised by a relatively low phosphate content around $3 \mathrm{mg} \mathrm{P} / \mathrm{dm}^{3}$ (Table 3)

\section{RESULTS AND DISCUSSION}

A key step underpinning the choice of reactive material for the P-removal is for sorption capacity to be estimated. This, in fact, depends on many factors, like the physical and chemical properties of the material, as well as contact time and concentration of $\mathrm{P}$ in the solution. By reference to the value for sorption capacity characterising a material, it is possible to calculate an estimated working time of the filter, in relation to the assumed time of contact between the material and the adsorbate [Bus et al., 2014].

The laboratory trials identified the phosphorus sorption capacities, but the results in respect of phosphate ions adsorbed by all materials were also analysed using the Langmuir model to evaluate the associated parameters (Figure 3-4). The maximum sorption capacities of powdered ceramsite and brick dust, as determined experimentally, were $0.593 \mathrm{mg} \mathrm{P} / \mathrm{g}$ and $0.455 \mathrm{mg}$ $\mathrm{P} / \mathrm{g}$, respectively. The parameters of the model obtained using linear regression analysis were $\mathrm{q}_{\mathrm{m}}=0.5952 \mathrm{mg} \mathrm{P} / \mathrm{g}$ and $\mathrm{K}_{\mathrm{L}}=0.4283$ for PK and $\mathrm{q}_{\mathrm{m}}=0.4539 \mathrm{mg} \mathrm{P} / \mathrm{g}$ and $\mathrm{K}_{\mathrm{L}}=0.206$ for BD.

The sorption data obtained for the powdered materials studied fit to the linear form of the 
Table 2. Parameters characterising the particle-size distribution of PK and BD adsorption experiments

\begin{tabular}{|l|l|c|c|}
\hline \multicolumn{1}{|c|}{ Parameter } & \multicolumn{1}{c|}{ Unit } & PK & BD \\
\hline $\begin{array}{l}\text { Surface Weighted Mean } \\
\mathrm{D}[3,2]\end{array}$ & {$[\mu \mathrm{m}]$} & 7.576 & 13.363 \\
\hline $\begin{array}{l}\text { Volume Weighted Mean } \\
\mathrm{D}[4,3]\end{array}$ & {$[\mu \mathrm{m}]$} & 36.421 & 52.699 \\
\hline Diameter $d(0.1)$ & {$[\mu \mathrm{m}]$} & 3.643 & 4.777 \\
\hline Diameter $d(0.5)$ & {$[\mu \mathrm{m}]$} & 24.110 & 31.870 \\
\hline Diameter $d(0.9)$ & {$[\mu \mathrm{m}]$} & 85.279 & 132.860 \\
\hline
\end{tabular}

Table 3. Characteristics of the wastewater used in this study

\begin{tabular}{|c|c|c|c|c|c|}
\hline Value & $\begin{array}{c}\mathrm{P}_{\mathrm{PgO}} \mathrm{PO}_{4} \\
\mathrm{dm}^{3}\end{array}$ & $\mathrm{pH}$ & $\begin{array}{l}\text { Alkalinity } \\
\mathrm{mval} / \mathrm{dm}^{3}\end{array}$ & $\begin{array}{c}\text { Acidity } \\
\mathrm{mval} / \\
\mathrm{dm}^{3}\end{array}$ & $\begin{array}{c}\text { Conductivity } \\
\mu \mathrm{S} / \mathrm{cm}\end{array}$ \\
\hline Average & 2.70 & 10.68 & 1.53 & 1554.5 & 7.59 \\
\hline Minimum & 2.0 & 7.5 & 0.6 & 898.0 & 7.37 \\
\hline Maximum & 3.1 & 12.2 & 2.3 & 1742 & 7.75 \\
\hline STD & 0.4 & 1.70 & 0.62 & 322.87 & 0.14 \\
\hline
\end{tabular}

All results - expressed as means for samples from the three trials (plots) - were analysed statistically using one-way analysis of variance at $p<0.05$ with STATISTICA PL software (StatSoft Poland).

Langmuir equation (Fig. 3). The higher $\mathrm{R}^{2}$ of PK and BD (0.9997 and 0.9954 respectively) reveals a very good mathematical fit between the experimental data and the Langmuir isotherm model. The results showed that $\mathrm{q}_{\mathrm{m}}$ remains highest for the phosphate-ion sorption onto powdered ceramsite, with brick dust proving less effective. The sorption mechanism at work is doubtless similar to that characterising clay or aluminosilicates, further denoting monolayer adsorption on to a homogeneous surface, with no interaction between the adsorbed molecules at the concentrations tested [Chen et al. 2010]. The chemical properties of media are known to play a critical role in this regard, with cations such as $\mathrm{Ca}^{2+}, \mathrm{Al}^{3+}$ and $\mathrm{Fe}^{3+}$ in reactive material proving important when it comes

a)

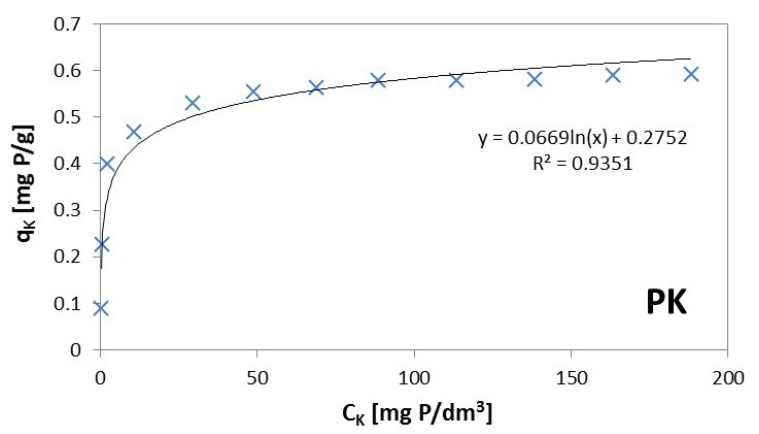

to the P-removal from wastewater via physical/ chemical processes [Johansson Westholm, 2006, Moharami and Jalali, 2015, Yan et al. 2010]. The source of ingredients having an affinity for phosphorus are the aforementioned aluminosilicates present in the raw materials used in producing expanded clay and brick. Therefore, it is possible for the investigations on the composition of powdered ceramsite and brick dust to reveal the presence of calcium and iron oxides and aluminosilicates. Nevertheless, PK and BD differ in the chemical composition as - while the aluminium contents are similar at around $17-18 \%$, powdered ceramsite has more iron and calcium than brick dust (Table 2). The oxide ratio $\mathrm{CaO}: \mathrm{Al}_{2} \mathrm{O}_{3}: \mathrm{Fe}_{2} \mathrm{O}_{3}$ for the analysed materials is $0.82: 1.36: 1$ (PK) and 0.3:2.58:1 (BD). Thus, the mechanism of sorbing $\mathrm{P}$ from aqueous solution may mainly reflect the presence of aluminum in the powdered materials.

Table 4 compares the values for the sorption capacities obtained in this work and other studies. The values in the case of both powdered ceramsite and brick dust are found to be comparable with those characterising other materials, implying a potential application in removing phosphate from wastewater. While PK and BD are of very low sorption capacity in comparison with other materials, it is known that the media of low phosphorus-removal efficiencies can often be modified with a view to these being enhanced. The sorption capacity of clay minerals can be increased by modification, and a literature review has shown that the phosphate removal can benefit from the presence of larger amounts of calcium, iron or aluminium in reactive materials. For example, clays modified to include $\mathrm{NaCl}, \mathrm{CaCl}_{2}$ or $\mathrm{FeCl}_{3}$ as adsorbents can be applied in removing $\mathrm{P}$ from aqueous solution. Batch studies showed the $\mathrm{P}$ sorption capacities due to the presence of $\mathrm{Fe}$-adsorbents in bentonite $(1.31 \mathrm{mg} / \mathrm{g})$, calcite

b)

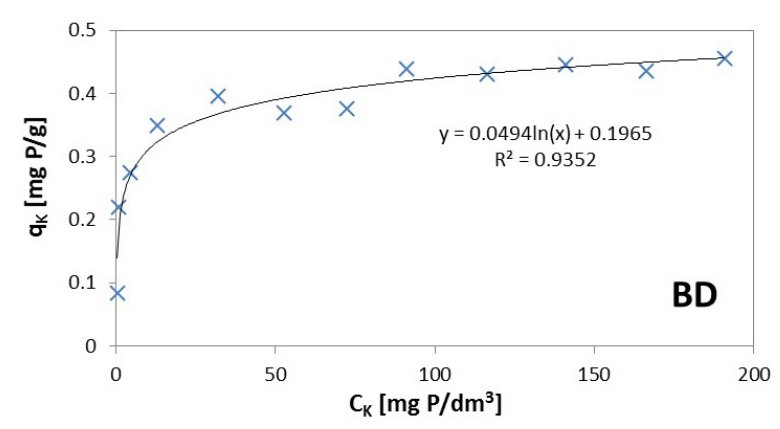

Figure 3. Sorption isotherms for $\mathrm{PO}_{4}^{3-}$ in relation to the powdered materials used 
a)

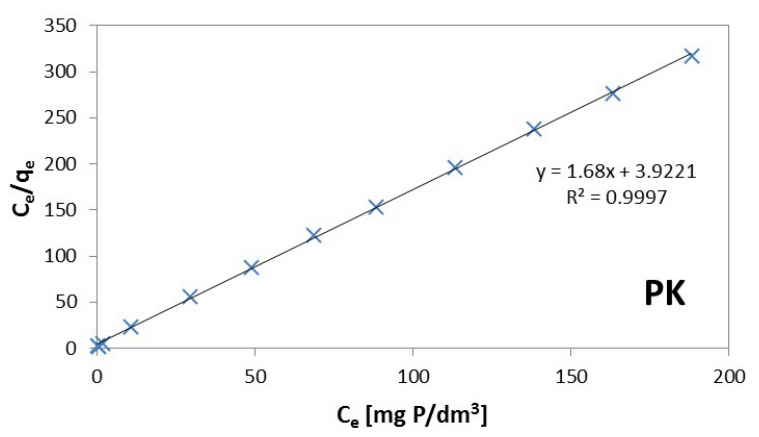

b)

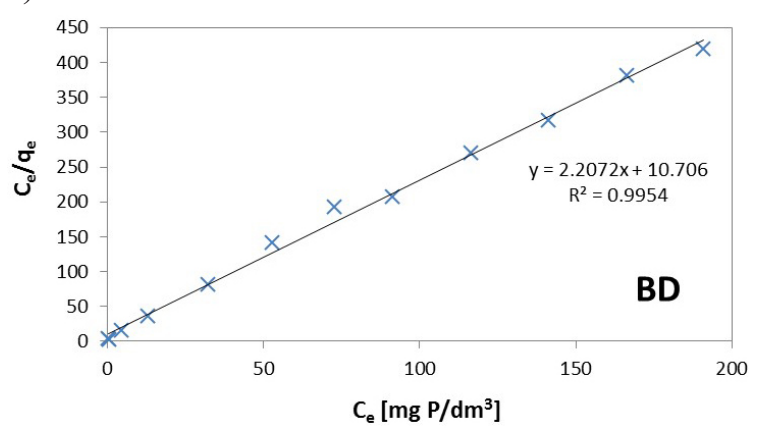

Figure 4. Langmuir isotherms for $\mathrm{P}$-sorption on $\mathrm{PK}$ and $\mathrm{BD}$

(1.97 mg/g), kaolinite (1.31 mg/g), and zeolite (1.58 mg/g) being improved by 467, 107, 409, and $427 \%$, respectively, as compared with the unmodified adsorbents - bentonite $(0.28 \mathrm{mg} / \mathrm{g})$, calcite $(1.82 \mathrm{mg} / \mathrm{g})$, kaolinite $(0.32 \mathrm{mg} / \mathrm{g})$, and zeolite $(0.37 \mathrm{mg} / \mathrm{g})$ [Moharami and Jalali, 2015 ].

A literature review reveals that - compared with other materials - powdered ceramsite and brick dust are indeed of low sorption capacity.

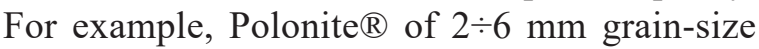
and Leca ${ }^{\circledR}$ of $4 \div 10 \mathrm{~mm}$ grain-size are characterised by the values of 40.9 and $5.1 \mathrm{mg} \cdot \mathrm{P} / \mathrm{g}$ respectively [Kaczmarczyk et. al., 2017]. Boujelben et al. (2008) drew on the parameters of the Langumir isotherm equation to determine the maximum sorption capacity for three sorption materials $-0.88,1.5$ and $1.75 \mathrm{mg} \mathrm{P} / \mathrm{g}$ respectively, in the cases of naturally iron oxidecoated sand (NCS), synthetic iron oxide-coated sand (SCS) and iron oxide-coated crushed brick (CB). In turn, the Pollytag $\AA$ aggregate formed from fly ash is seen to be characterised by a sorption capacity of $32.24 \mathrm{mg} \mathrm{P} / \mathrm{g}$ [Bus et al., 2014]. Powdered freshwater mussel shells have a P-sorption capacity of $6.95 \mathrm{mg} \mathrm{P} / \mathrm{g}$ [Xiong et al., 2011]. Vianna et al. (2016) studied various types of sun coral powder as adsorbents and found maximum P-removal capacities of raw, physically-modified and chemically-modified material at the levels of $6.8,7.0$ and $9.6 \mathrm{mg} \mathrm{P} / \mathrm{g}$, respectively. The so-called red mud, as a waste residue from alumina refineries, is characterised by a sorption capacity similar to that manifested by powdered ceramsite. Huang et al. (2008) noted a P-sorption capacity for red mud of 0.58 $\mathrm{mg} / \mathrm{g}$. One other powdered material - clinker ash - was in turn found to achieve sorption at a level of $0.29 \mathrm{mg} \mathrm{P} / \mathrm{g}$ [Sima et al. 2018].

The batch tests carried out using two types of powdered materials showed a significant degree of phosphate removal from wastewater (Figs. 5 and 6). The application of $0.5 \mathrm{~g}$ of powdered material per litre of wastewater ensures a noticeable reductions in the phosphate-phosphorus

Table 4. Comparison of various clay materials in terms of the phosphate-adsorption capacities

\begin{tabular}{|l|c|l|}
\hline \multicolumn{1}{|c|}{ Material } & $\begin{array}{c}\text { Sorption capacity } \\
\text { (mg P/g) }\end{array}$ & References \\
\hline Sepiolite & 0.60 & Ooi et al. (2017) \\
\hline Calcium-rich sepiolite & 32.0 & Yin et al. (2011) \\
\hline Na-natural zeolite & 2.19 & Wu et al. (2006) \\
\hline Bentonite & 5.54 & Yan et al. (2010) \\
\hline La(III)-modified bentonite & 5.60 & Kasprzyk and Gajewska (2017) \\
\hline La(III)-modified bentonite & 14.0 & Kuroki et al. (2014) \\
\hline Magnetic illite clay & 5.48 & Chen et al. (2016) \\
\hline Hydrous iron oxide modified diatomite & $4.89-35.71$ & Wang et al. (2016) \\
\hline Akadama clay & 5.88 & Wang et al., (2018) \\
\hline Acid-activated akadama clay & 9.19 & Wang et al., (2018) \\
\hline Modified montmorillonite (C ${ }_{1.0}$-AlPMt) & 11.89 & Ma et al. (2016) \\
\hline Tunisian clay soils & $19.53-31.84$ & Hamdi and Srasra. 2008 \\
\hline Powdered ceramsite & 0.593 & This study \\
\hline Brick dust & 0.455 & This study \\
\hline
\end{tabular}




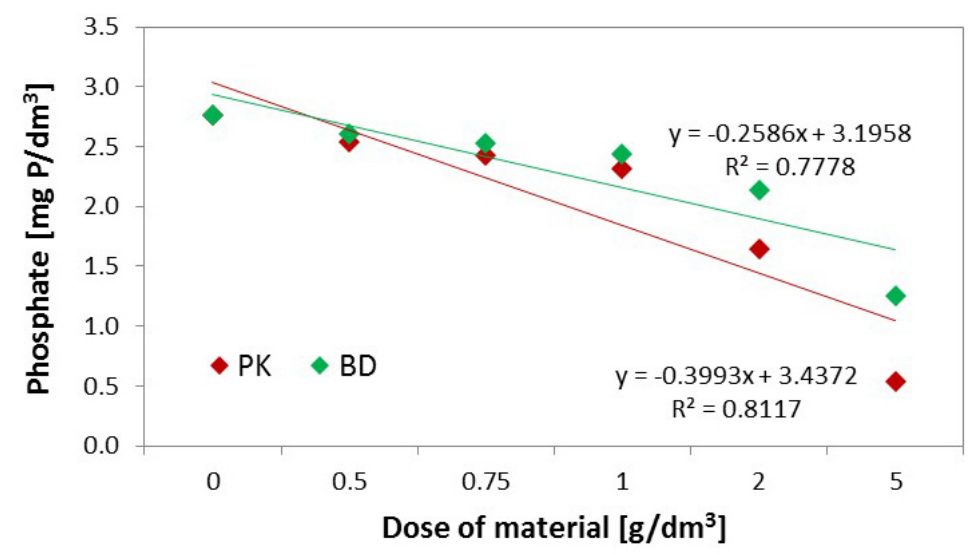

Figure 5. Phosphate concentration in wastewater in line with the applied dose of powdered material

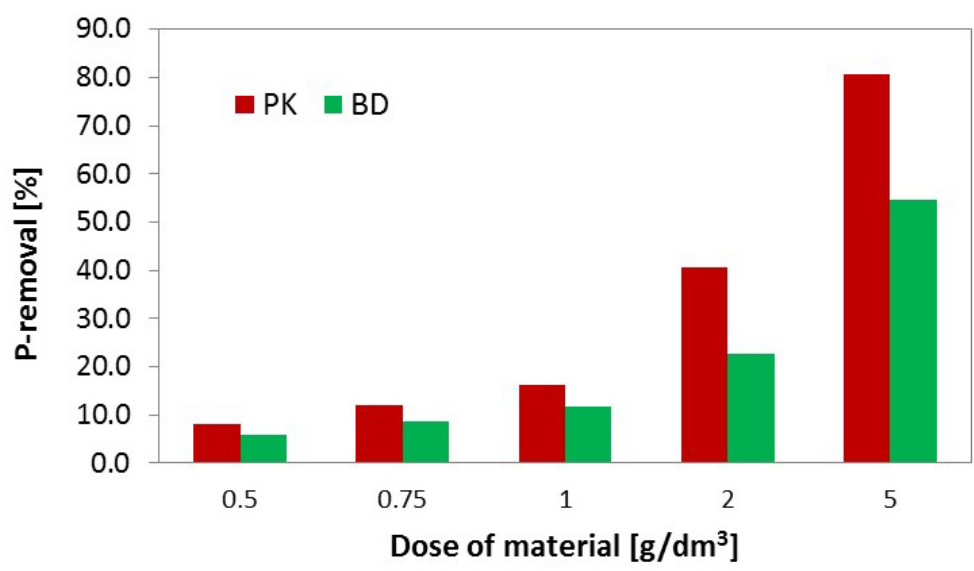

Figure 6. Phosphate removal from wastewater in line with the applied dose of powdered material

concentrations, to $2.54 \pm 0.3 \mathrm{mg} \mathrm{P} / \mathrm{dm}^{3}$ (for PK) and $2.61 \pm 0.3 \mathrm{mg} \mathrm{P} / \mathrm{dm}^{3}$ (for $\mathrm{BD}$ ). This equates to percentage removal efficiencies of $8.1(\mathrm{PK})$ and $5.7(\mathrm{BD})$. With consecutively higher doses of powdered ceramsite or brick dust phosphate levels are further lowered. With the $0.75 \mathrm{~g} / \mathrm{dm}^{3}$ dose, the phosphate concentration in the treated wastewater was $2.43 \pm 0.32 \mathrm{mg} \mathrm{P} / \mathrm{dm}^{3}$ for powdered ceramsite and $2.53 \pm 0.31 \mathrm{mg} \mathrm{P} / \mathrm{dm}^{3}$ for brick dust; while with a $1 \mathrm{~g} / \mathrm{dm}^{3}$ dose to the respective resulting figures are $2.32 \pm 0.31$ and $2.44 \pm 0.3 \mathrm{mg} \mathrm{P} /$ $\mathrm{dm}^{3}$. Higher doses caused noticeable phosphorus removal from wastewater in the case of powdered ceramsite. The use of 2 and $5 \mathrm{~g}$ BD per liter of wastewater resulted in a decrease in phosphate concentration to $2.14 \pm 0.31 \mathrm{mg} \mathrm{P} / \mathrm{dm}^{3}$ and 1.25 $\pm 0.39 \mathrm{mg} \mathrm{P} / \mathrm{dm}^{3}$, respectively. In turn, dosing of powdered ceramsite in the amount of $2 \mathrm{~g} / \mathrm{dm}^{3}$ and $5 \mathrm{~g} / \mathrm{dm}^{3}$ reduced the phosphate phosphorus concentration to $1.64 \pm 0.28 \mathrm{~g} / \mathrm{dm}^{3}$ and $0.53 \pm 0.31 \mathrm{~g} /$ $\mathrm{dm}^{3}$. At a dose of $2 \mathrm{~g} / \mathrm{dm}^{3}$, the phosphate removal efficiency was thus $22.6 \pm 2.7 \%$ (BD) and 40.7 $\pm 2.8 \%$ (PK). However, at the highest dose of powdered substances, a phosphate reduction of $54.7 \pm 8.8 \%$ and $80.7 \pm 8.7 \%$ was achieved for $\mathrm{BD}$ and $\mathrm{PK}$, respectively.

For comparison, Sima et al. (2018) studied the use of clinker ash $\left(11.7 \% \mathrm{Al}_{2} \mathrm{O}_{3}, 6.0 \% \mathrm{CaO}\right.$ and $5.3 \% \mathrm{Fe}_{2} \mathrm{O}_{3}$ ) in the P-removal as regards aqueous solutions. Increasing the clinker ash dosage from 2.0 to $6.0 \mathrm{~g}$ per $100 \mathrm{~cm}^{3}$ of wastewater increased the efficiency of P-removal from $21.5 \%$ to $76 \%$. Although higher doses of clinker ash were used than in our studies, and the chemical composition of all powdered substances was similar, Sima et al. (2018) obtained lower efficiency of phosphorus compounds removal.

The addition of $\mathrm{PK}$ and $\mathrm{BD}$ to wastewater leads, not only to phosphate removal, but also to alkalisation of the medium (Figs. 7 and 8). A pH increase from the initial 7.56 to a maximum of 7.69 was noted using $5 \mathrm{~g}$ of PK per litre of wastewater. In the case of brick dust application, the $\mathrm{pH}$ increase was more limited, to a maximum of 7.59. However, in the course of the latter tests, the alkalinity of the wastewater was between 10.68 


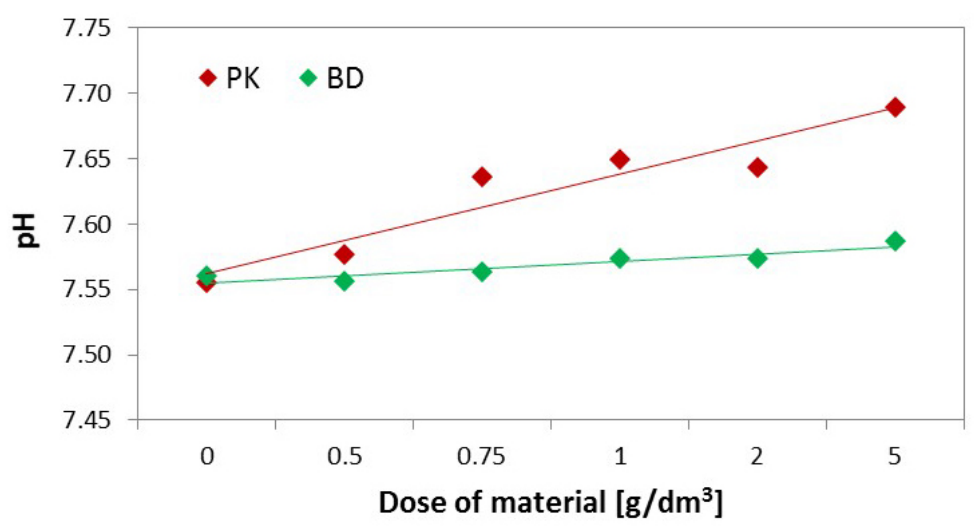

Figure 7. The impact of the powdered materials on the $\mathrm{pH}$ of wastewater

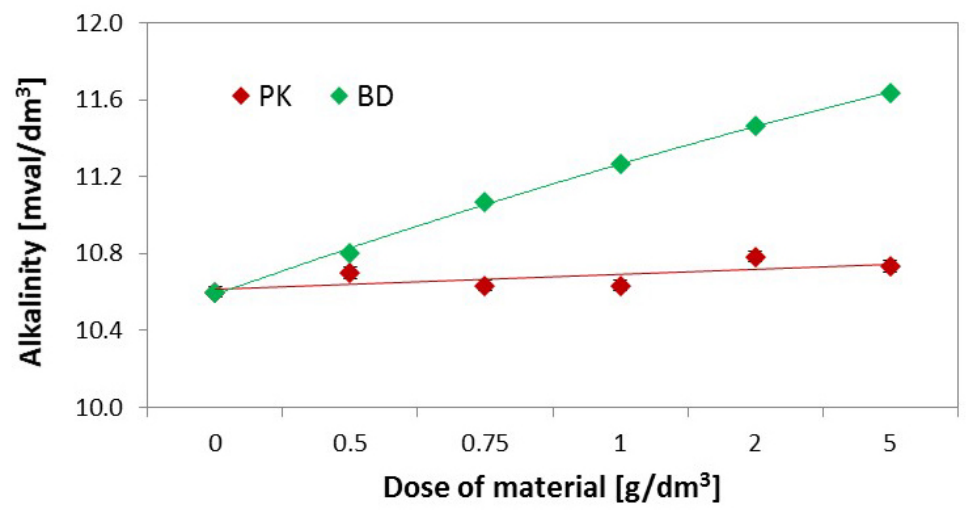

Figure 8. The impact of the powdered materials on the alkalinity of wastewater

and $11.63 \mathrm{mval} / \mathrm{dm}^{3}$. In contrast, the alkalinity of the wastewater to which powdered ceramsite had been added was not so high, with $\mathrm{pH}$ in the range $10.68-10.78 \mathrm{mval} / \mathrm{dm}^{3}$.

The studies conducted revealed a certain usefulness of powdered substances - powdered ceramsite and brick dust - where the removal of phosphorus compounds from wastewater was concerned. Nevertheless, in terms of their reactivity, the tested materials were found to be of low sorption capacity, to the extent that their use in, for example filters, may prove of low efficiency. It is therefore reasonable to use powdered substances as part of a simultaneous effort to remove phosphorus by means of the biological wastewater treatment. Powdered ceramsite has been tested to improve activated sludge processes, and its presence at $0.75 \mathrm{~g} /$ $\mathrm{dm}^{3}$ in a Keramsite-Sequencing Batch Reactor does prove beneficial to the aforementioned biological treatment processes. On the one hand, sedimentation and morphological properties of the activated sludge are improved, while on the other there is an intensification - and above all a marked stabilisation - of the unit processes by which organic carbon, nitrogen and phosphorus are all removed from wastewater. The powdered ceramsite additive stimulates the growth of microorganisms, i.a. by enhancing the microbiological biodiversity [Masłoń et al. 2019]. In other studies, powdered ceramsite was tested in aerobic granular sludge technology [Czarnota et al., 2018, Czarnota et al. 2019], with addition to the reactors operating at organic loading rate values of $2.10 \mathrm{~g} \mathrm{COD} /\left(\mathrm{dm}^{3} \cdot \mathrm{d}\right)$ and $1.0 \mathrm{~g} \mathrm{COD} /\left(\mathrm{dm}^{3} \cdot \mathrm{d}\right)$ found to provide for biogranulation [Czarnota et al. 2019].

\section{CONCLUSIONS}

The work revealed a certain usefulness of powdered substances, i.e. powdered ceramsite (expanded clay) and brick dust, where the removal of phosphorus compounds from wastewater was concerned. In adsorption experiments, the maximum sorption capacities of powdered ceramsite and brick dust were determined experimentally at 0.593 and $0.455 \mathrm{mg} \mathrm{P} / \mathrm{g}$, respectively. The batch experiments showed that the efficiency of phosphate removal depends on the type of powdered material, as well as their chemical compositions 
and doses. The concentration of phosphate was shown to be lower in all treatment tests using both powdered ceramsite and brick dust. However, the highest phosphorus removal efficiencies were $54.7 \pm 8.8 \%$ and $80.7 \pm 8.7 \%$, for brick dust and powdered ceramsite, respectively, at doses of $5.0 \mathrm{~g} / \mathrm{dm}^{3}$ of wastewater.

The current outcome suggests that powdered ceramsite and brick dust are reactive materials and can be used as a sorbent along with metal ions $\left(\mathrm{Ca}^{2+}, \mathrm{Al}^{3+}\right.$, and $\left.\mathrm{Fe}^{3+}\right)$, when it comes to the P-removal from wastewater. Moreover, the spent powdered material could be repurposed as a phosphate plant fertiliser, in a way that would reduce the costs of disposal and increase the commercial value.

\section{REFERENCES}

1. Boujelben N., Bouzid J., Elouear Z., Feki M., Jamoussi F., Montiel A. 2008. Phosphorus removal from aqueous solution using iron coated natural and engineered sorbents. Journal of Hazardous Materials, 151, 103-110.

2. Bowes M. J., Jarvie H. P., Halliday S. J., Skeffington R. A., Wade A. J., Loewenthal M., 2015. Characterising phosphorus and nitrate inputs to a rural river using high-frequency concentration-flow relationships. Science of the Total Environment, 511, 608-620.

3. Bunce J.T., Ndam E., Ofiteru I.D., Moore A., Graham D.W. 2018. A Review of Phosphorus Removal Technologies and Their Applicability to Small-Scale Domestic Wastewater Treatment Systems. Frontiers in Environmental Science, 2018, 6, 8.

4. Bus A., Kaczmarczyk A., Baryła A. 2014. Choosing of reactive material for phosphorous removal from water and wastewater on the example of lightweight aggregate Pollytag®. Inżynieria Ekologiczna, 39, 33-41 (in Polish)

5. Caravelli A.H., Contreras E.M., Zaritzky N.E. 2010. Phosphorous removal in batch systems using ferric chloride in the presence of activated sludges. Journal of Hazardous Materials, 177, 199-208.

6. Chen J., Yan L. G., Yu H. Q., Li S., Qin L. L., Liu G. Q., Li Y. F., Du B. 2016. Efficient removal of phosphate by facile prepared magnetic diatomite and illite clay from aqueous solution. Chemical Engineering Journal, 287, 162-172.

7. Chen R., Zhang Z., Feng C., Lei Z., Li Y., Li M., Shimizu K., Sugiura N. 2010. Batch study of arsenate (V) adsorption using Akadama mud: effect of water mineralization. Applied Surface Science, 256 (9), 2961-2967.
8. Cieślik B., Konieczka P. 2017. A review of phosphorus recovery methods at various steps of wastewater treatment and sewage sludge management. The concept of "no solid waste generation" and analytical methods. Journal of Cleaner Production, 142, 1728-1740.

9. Cucarella V., Mazurek R., Zaleski T., Kopeć M., Renman G. 2009. Effect of Polonite used for phosphorus removal from wastewater on soil properties and fertility of a mountain meadow. Environmental Pollution, 157(7), 2147-2152.

10. Cucarella, V., Renman, G. 2009. Phosphorus sorption capacity of filter materials used for on-site wastewater treatment determined in batch experiments - a comparative study. Journal of Environmental Quality, 38, 381-392

11. Czarnota J., Masłoń A. 2019. Biogranulation and Physical Properties of Aerobic Granules in Reactors at Low Organic Loading Rate and with Powdered Ceramsite Added. Journal of Ecological Engineering, 20(9), 202-210.

12. Czarnota J., Masłoń A., Zdeb M. 2018. Powdered keramsite as unconventional method of AGS technology support in GSBR reactor with minimumoptimum. E3S Web of Conferences, 44, 00024.

13. Hamdi N., Srasra E. 2008. Sorption of phosphate from acidic wastewater into three Tunisian type clay soils. Journal of Water Chemistry and Technology, 30, 4, 208-214.

14. Huang W.W., Wang S.B., Zhu Z.H., Li L., Yao X.D., Rudolph V., Haghseresht F. 2008. Phosphate removal from wastewater using red mud, Journal of Hazardous Materials, 158, 35-42.

15. Johansson Westholm L. 2006. Substrates for phosphorus removal - Potential benefits for on-site wastewater treatment. Water Research, 40, 23-36.

16. Kaczmarczyk A., Woja K., Bliska P., Baryła A., Bus A. 2017. The efficiency of filtration materials (Polonite ${ }^{\circledR}$ and Leca ${ }^{\circledR}$ ) supporting phosphorus removal in on site treatment systems with wastewater infiltration. Infrastructure and Ecology Rural Areas, IV, 1401-1413.

17. Kasprzyk M., Gajewska M. 2017. Preliminary results from application Phoslock ${ }^{\circledR}$ to remove phosphorus compounds from wastewater. Journal of Ecological Engineering, 18(4), 82-89.

18. Kasprzyk M., Gajewska M. 2019. Phosphorus removal by application of natural and semi-natural materials for possible recovery according to assumptions of circular economy and closed circuit of P. Science of the Total Environment, 650, 249-256.

19. Kim D.-G., Yoo I.S., Park B.-S., Lee Y.-H., Kim S.-H., Chang D., Sunwoo Y., Shin H.-S., Eo Y.-D., Hong K-H. 2012. Alternative technique for removal of phosphorus in wastewater using chemically surface-modified silica filter. Journal of Industrial and 
Engineering Chemistry, 18(5), 1560-1563.

20. Kõiv M., Liira M., Mander Ü., Mõtlep R., VohlaC., Kirsimäe K. 2010. Phosphorus removal using Carich hydrated oil shale ash as filter material - The effect of different phosphorus loadings and wastewater compositions. Water Research, 44, 18, 5232-5239.

21. Kuroki V., Bosco G.E., Fadini P.S., Mozeto A.A., Cestari A.R., Carvalho W.A. 2014. Use of a La(III)modified bentonite for effective phosphate removal from aqueous media. Journal of Hazardous Materials, 274, 124-131.

22. Lanham A. B., Oehmen A., Saunders A. M., Carvalho G., Nielsen P. H., Reis M.A.M. 2013. Metabolic versatility in full-scale wastewater treatment plants performing enhanced biological phosphorus removal. Water Research, 47(19), 7032-7041

23. Li J., Li B., Huang H., Lv X., Zhao N., Guo G., Zhang D. 2019. Removal of phosphate from aqueous solution by dolomite-modified biochar derived from urban dewatered sewage sludge. Science of the Total Environment, 687, 460-469.

24. Li J., Wu B., Zhou T., Chai X. 2018. Preferential removal of phosphorus using modified steel slag and cement combination for its implications in engineering applications. Environmental Technology \& Innovation, 10, 264-274.

25. Liu Y., Sheng X., Dong Y., Ma Y. 2012. Removal of high-concentration phosphate by calcite: Effect of sulfate and $\mathrm{pH}$. Desalination, 289, 66-71.

26. Ma L., Zhu J., Xi Y., Zhu R., He H., Liang X., Ayoko G.A. 2016. Adsorption of phenol, phosphate and $\mathrm{Cd}(\mathrm{II})$ by inorganic-organic montmorillonites: A comparative study of single and multiple solute. Colloids and Surfaces A: Physicochemical and Engineering Aspects, 497, 63-71.

27. Masłoń A. 2016. Phosphorus removal from aqueous solutions using cement milk. Gaz, Woda i Technika Sanitarna, 12, 457-461 (in Polish)

28. Masłoń A., Tomaszek J.A., Zamorska J., Zdeb M., Piech A., Opaliński I., Jurczyk Ł. 2019. The impact of powdered keramsite on activated sludge and wastewater treatment in a sequencing batch reactor. Journal of Environmental Management, 237, 305-312.

29. Moharami S., Jalali M. 2015. Use of modified clays for removal of phosphorus from aqueous solutions. Environmental Monitoring and Assessment, 187(10), 639.

30. Ooi K., Sonoda A., Makita Y., Torimura M. 2017. Comparative study on phosphate adsorption by inorganic and organic adsorbents from a diluted solution. Journal of Environmental Chemical Engineering, 5 (4), 3181-3189.

31. Sima T.V., Letshwenyo M.W., Lebogang L. 2018. Efficiency of waste clinker ash and iron oxide tailings for phosphorus removal from tertiary wastewater: Batch studies. Environmental Technology \&Innovation, 11, 49-63.

32. Totczyk G., Klugiewicz I., Pasela R., Górski Ł. 2015. Removal of Phosphates with Post-technological Sludge from Water Treatment Plant. Rocznik Ochrona Środowiska, 17(2), 1660-1673 (in Polish).

33. Trikoilidou E., Samiotis G., Bellos D., Amanatidou E. 2016. Sustainable operation of a biological wastewater treatment plant. IOP Conf. Series: Materials Science and Engineering, 161, 012093

34. Vianna M.T.G., Marques M., Bertolino L.C. 2016. Sun coral powder as adsorbent: Evaluation of phosphorus removal in synthetic and real wastewater. Ecological Engineering, 97, 13-22.

35. Wang Y., He H., Zhang N., Shimizu K., Lei Z., Zhang Z. 2018. Efficient capture of phosphate from aqueous solution using acid activated akadama clay and mechanisms analysis. Water Science and Technology, 78(7), 1603-1614.

36. Wang Z., Lin Y., Wu D., Kong H. 2016. Hydrous iron oxide modified diatomite as an active filtration medium for phosphate capture. Chemosphere, 144, 1290-1298.

37. Wu D., Zhang B., Li C., Zhang Z., Kong H. 2006. Simultaneous removal of ammonium and phosphate by zeolite synthesized from fly ash as influenced by salt treatment. Journal of Colloid and Interface Science, 304 (2), 300-306.

38. Xiong J., Qin Y., Islam E., Yue M., Wang W. 2011. Phosphate removal from solution using powdered freshwater mussel shells. Desalination, 276, 317-321.

39. Yadav D., Kapur M., Kumar P., Kumar Mondal M. 2015. Adsorptive removal of phosphate from aqueous solution using rice husk and fruit juice residue. Process Safety and Environmental Protection, 94, 402-409.

40. Yan L., Xu Y., Yu H., Xin X., Wei Q., Du B. 2010. Adsorption of phosphate from aqueous solution by hydroxy-aluminum, hydroxy-iron and hydroxyiron-aluminum pillared bentonites. Journal of Hazardous Materials, 179 (1-3), 244-250.

41. Yin H., Yun Y., Zhang Y., Fan C. 2011. Phosphate removal from wastewaters by a naturally occurring, calcium-rich sepiolite. Journal of Hazardous Materials, 198, 362-369. 